\title{
Effect of Topping and Gibberellic Acid Combinations on Growth, Flowering and yield Components of Husk Tomato (Physalis pruinosa, L.)
}

\author{
Doaa M. Mostafa \\ Veg. Res. Dept., Hort. Inst., Agric. Res. Center, Alex., Egypt
}

\begin{abstract}
This investigation was aimed to study the effects of interaction of apex removal (topping) treatments at varying interval leaf stages $\left(4,5\right.$ and $6^{\text {th }}$ leaf stage) and application of gibberellic acid $\left(\mathrm{GA}_{3}\right)$ at different rates $(0,20$ and $40 \mathrm{mg} / \mathrm{L})$ on growth, flowering characters, yield and its components of husk tomato (Physalis pruinosa, L.) cultivar Balady. The obtained results showed that topping at 4,5 and $6^{\text {th }}$ leaf stage stimulated growth of basal branches and increased number of flowers which were achieved at the early yield, likewise, application of $\mathrm{GA}_{3}$ either at 20 or $40 \mathrm{mg} / \mathrm{L}$ overcame the delaying effect of topping on flowering and at the same time enhanced growth of basal branches. In conclusion total yield increased, by $4^{\text {th }}$ leaf stage of topping under $40 \mathrm{mg} / \mathrm{L}$ of $\mathrm{GA}_{3}$ combination, which sassociated with increased number and average weight of fruits.
\end{abstract}

Keywords: Husk tomato, topping, gibberellic acid, flowering, growth, yield.

\section{INTRODUCTION}

Husk tomato (Physalis pruinosa,L.,) is a member of the family solanaceae. It has different names such as husk tomato, winter cherry, strawberry-tomato, tomatillo fruit (Biachini and Corbetta, 1977) and Haran Kish as commonly known in Egypt. Husk tomato grown in a semi tropical regions and it is cultured in Egypt in limited areas near big cities and it can be cultured in the south of El Wady and the new reclaimed regions in Toshki. About 300 acres are cultivated with husk tomato. In Egypt the production is about $3000-4500$ $\mathrm{kg} / \mathrm{fed}$. of the fruits (Agricultural Statistics News Letters, 1996). Harankish fruits is small round in shape, yellow to yellow greenish in colour, $2 \mathrm{~cm}$ in diameter, coverd with thin husk and containing a large of whitish seeds (Bianchini and corbetta, 1977).

It has been reported that husk tomato is cultivated to eat its fruits fresh because of its high nutritional value, its importance in the draining of bile juice and its importance role in activation of liver functions as a medical plant for treating Kidney disease (it purportedly disintegrated kidney stones) and disease of urinary passages (Stary, 1983). Today, it is used in homeopathy for the same purpose. Husk tomato, is usually used for local consumption as a snake food or for exportation. In Egypt, cultivation, production and consumption of this fruit are still limited in comparisonwith other fruits. The fruits are perishable, having high moisture content, therefore it is rapidly subjected to spoilage. Also, it has a short marketing season starting from October till January. Due to its very acceptable and popular sweet taste with acidic nature, its high nutritive value, medical importance, and consumption in Egypt, in gradual increase.

No attention has been paid to increase the fruits yield, and there is a very little available data in the literature regarding cultivated area, production, chemical composition, even its industrial utilization. Further studies by Charles (1948) and Wien and Minotti (1988) showed that apex removal (topping) of the main stem of tomato at an early leaf stage of growth led to an increase in both basal branches and flowering clusters number. However, topping treatment was 
seen to have a delaying effect on flowering and early yield (Knott, 1928; Westover, 1942 and Charles, 1948).

Folair application of gibberellic acid seemed to accelerate flowering without affecting the number of nodes below the first flower cluster (Wittweret al., 1957; Rappaport, 1957 and Robert, 1959) and increased fruit size (Sawhnay and Greyson, 1972). Therefore, this work was designed to examine and explain the interaction effect of field application of gibbellic acid and apex removal of the main stem of husk tomatoes on flowering time, number of basal branches and number of flowers, as well as yield and its components.

\section{MATERIALS AND METHODS}

This investigation was carried out at private farm, located in Burg ElArab region about $60 \mathrm{~km}$. west of Alexandria, Egypt, during both successive growing seasons of 2011 and 2012.Soil physical and chemical properties of the experimental sites during winter season of 2011 and 2012, also average air temperature $\left(\mathrm{C}^{\circ}\right)$ were presented in Tables (1 and 2) as follows:

Seeds of the husk tomato cultivar (Balady) were sown on the first of August 2011 and 2012.When the seedlings were at the fourth, fifth and sixth true leaf-stage at 46, 50 and 54 days after sowing seeds, respectively, apex of each main stem was pinched and removed (topped) using a sterilized scissors, and at the same time plants were treated with fungicide.

The seedlings were transplanted into field on first week of October in 2011and 2012. The conducted experiments were factorial experimants planted in a randomized complete blocks design by Waller and Duncan (1969), consisting of three blocks. The experimental unit was represented in 4 rows. Spacing was $100 \mathrm{~cm}$., between rows and $35 \mathrm{~cm}$. within plants.

The factorial experiments consisted of the combinations of three levels of gibberellic acid $(0,20$ and $40 \mathrm{mg} / \mathrm{L})$ and three leaf stages of topping (4, 5 and $6^{\text {th }}$ leaf stage) as well as the control treatment (untopping + without using $\mathrm{GA}_{3}$ ). Gibberellic acid was applied twice during the experiment, after 15 days following transplantation and after an interval of two weeks later. Gibberellic acid was applied as foliar spray by using an atomizer- type sprayer. All cultural practices as irrigation, fertilization and pests control were followed as control were followed as recommended for commercial production. Husk tomato fruits were picked at 5 days intervals, starting from December during both growing seasons. The fallowing parameters were determined:

1. Flowering time (i.e. the number of days from transplanting to flowering of $25 \%$ of husk tomato plants in each plot).

2. Number of basal branches (i.e. number of flowers and fruits per plant as well as yield per plant and average fruit weight were measured in a sample of six randomly taken plants from each plot).

3. Early yield (i.e. the weight of harvested fruits during the first three harvests).

4. Total yield (the total weight of all the harvested fruits during the entire harvesting time).

The obtained data for each studied season were, statistically, analysied seperately and comparisons among means were performed by using least significant difference (LSD) method, recorded by Waller and Duncan (1969). 
Table (1). Physical and chemical properties of experimental field soils average of both seasons (2011 and 2012)

\begin{tabular}{|c|c|c|c|c|c|c|c|c|c|c|c|c|}
\hline \multirow{2}{*}{$\begin{array}{c}\text { Soil } \\
\text { depth } \\
\text { (cm) }\end{array}$} & \multirow[t]{2}{*}{ Texture } & \multirow[t]{2}{*}{$\mathrm{pH}$} & \multirow{2}{*}{$\begin{array}{c}\mathrm{EC} \\
\mathrm{dS} / \mathrm{m}\end{array}$} & \multirow{2}{*}{$\begin{array}{l}\text { O.M } \\
(\%)\end{array}$} & \multirow{2}{*}{$\begin{array}{c}\text { Total } \\
\mathrm{Ca} \\
\mathrm{CO}_{3}\end{array}$} & \multicolumn{4}{|c|}{ Soluble cations (meq / $100 \mathrm{~g}$ soil) } & \multicolumn{3}{|c|}{$\begin{array}{l}\text { DTPA-extractable } \\
\text { (mg/kg) }\end{array}$} \\
\hline & & & & & & $\mathrm{Na}^{+}$ & $\mathrm{K}^{+}$ & $\mathrm{Ca}^{++}$ & $\mathrm{Mg}^{++}$ & $\mathrm{Fe}$ & Mn & Zn \\
\hline $0-30$ & Sandy & $8-19$ & 3.05 & 0.46 & 25.20 & 2.81 & 0.157 & 9.90 & 8.83 & 0.38 & 0.47 & 0.28 \\
\hline $30-60$ & loam & 7.95 & 2.54 & 0.50 & 25.15 & 3.32 & 0.074 & 8.71 & 3.30 & 0.35 & 0.43 & 0.27 \\
\hline $60-90$ & & 7.86 & 2.45 & 0.53 & 29.10 & 2.86 & 0.096 & 8.60 & 4.40 & 0.32 & 0.63 & 0.23 \\
\hline
\end{tabular}

Table (2). Average air temperature $\left(C^{\circ}\right)$ for Burg El-Arab region (Alexandria) during the winter seasons of (2011 / 20122012/2013)

\begin{tabular}{|c|c|c|c|c|c|c|}
\hline \multirow[b]{2}{*}{$\begin{array}{l}\text { Season } \\
\text { Month }\end{array}$} & \multicolumn{2}{|c|}{ Minimum } & \multicolumn{2}{|c|}{ Maximum } & \multicolumn{2}{|c|}{ Average } \\
\hline & $2011 / 2012$ & 2012/2013 & $2011 / 2012$ & $2012 / 2013$ & $2011 / 2012$ & 20122013 \\
\hline Aug. & 19 & 24 & 34 & 31 & 26 & 27 \\
\hline Sept. & 17 & 21 & 31 & 28 & 24 & 25 \\
\hline Oct. & 13 & 16 & 24 & 26 & 19 & 21 \\
\hline Nov. & 14 & 13 & 23 & 20 & 19 & 17 \\
\hline Dec. & 8 & 6 & 18 & 16 & 13 & 11 \\
\hline Jan. & 6 & 6 & 15 & 12 & 11 & 9 \\
\hline Feb. & 9 & 10 & 15 & 13 & 12 & 12 \\
\hline Mar. & 11 & 10 & 15 & 16 & 13 & 13 \\
\hline Apr. & 12 & 11 & 17 & 20 & 15 & 16 \\
\hline May. & 14 & 17 & 22 & 22 & 18 & 20 \\
\hline
\end{tabular}




\section{RESULTS AND DISCUSSION}

1-Flowering time, number of basal branches and number of flowers:

Data presented in Table (3) showed that the effects of apex removal (topping) and $\mathrm{GA}_{3}$ combinations on flowering time, number of basal branches and number of flowers per plant were significant during both seasons of 2011 and 2012.

Topping treatments, irrespective of leaf stage, significantly, have taken a larger time of days to flower (i.e. 52.2 days), compared with the untopping treatment (43.4 days). When the topping treatments were sprayed with $\mathrm{GA}_{3}$, either with 20 or $40 \mathrm{mg} / \mathrm{L}$. The flowering time was found the same as the control, indicating that early flowering was more affected by topping treatments. The reported improving effect of $\mathrm{GA}_{3}$ on floweringtime could be attributed to $\mathrm{GA}_{3}$ role in enhancing the flowering system through acceleration maturity of the vegetative parts preceeding flowering, without affecting the number of nodes below the first florescence (Wittwer, et al. 1957; Rappaport, 1957; Rubinstion and Nagoa, 1976; Wien and Miontte; 1988; Ghoneim, 2000 and Feleafel, 2001). On the other hand, Sanat (1968) found that foliar application of $\mathrm{GA}_{3}$, after transplanting and prior flowering, had no effect on flowering time.

Topping at the 4,5 and $6^{\text {th }}$ leaf stage led to a larger number of basal branches(13.1) and number of flowers(8.3) per plant than the control. These enhancing effects of topping at the different leaf stages were complemented by $\mathrm{GA}_{3}$ applications especially at $40 \mathrm{mg} / \mathrm{L}$. These increases in basal branches and number of flowers per plant over the control treatmentcould be explained on the basis that destruction of the apical dominance due to topping treatments probably stimulated the basal branches and consequently the number of flowers could be increased. Wien and Minotti (1988); Ghoneim (2000) demonstrated that topping treatment at $4^{\text {th }}$ leaf-stage, significantly, increased both basal branches and flowers numbers per plant. Other work by Wittwer et al. (1957) reported an enhancing response of tomato due to foliar application of $\mathrm{GA}_{3}$ in number of flowers per plant.

2-Yield and its components:

In 2011 and 2012 seasons, topping at the 4,5 and $6^{\text {th }}$ leaf stage, did not appear any effect on average fruit size compared with the untopping (Table 4). However, the interaction effects of topping and $\mathrm{GA}_{3}$ on theaverage fruit size were significant. For instance, $\mathrm{GA}_{3}$ up to $40 \mathrm{mg} / \mathrm{L}$ and topping plants at 4,5 and $6^{\text {th }}$ leaf stage achieved an increase on fruit weight $(6.1,5.8$ and $5.1 \mathrm{~g})$ each in turn. In this regard, Sawhney and Grayson (1971 and 1972) stated that application of $\mathrm{GA}_{3}$ prior to floral differentiation ( $6-8$ leaves) resulted in a multilocular ovary, which upon fertilization produced larger fruits as compared with the control treatment. Batal (1983) found that weight of muskmelon fruit increased when $\mathrm{GA}_{3}$ was applied at the 3 - 4 leaf stage.

Interactions effects of topping and $\mathrm{GA}_{3}$ combinations on fruit number per plant were significant (Table 4). Fruits number/plantwas reduced than the untreated treatment, when treatment combinations included topping at $6^{\text {th }}$ leaf stage. Meanwhile, the treatment including topping at $4^{\text {th }}$ leaf stage under using $\mathrm{GA}_{3}$ at 40 $\mathrm{mg} / \mathrm{L}$ resulted in the highest number of fruits per plant (11.9). These explained the predominant effect of topping at early leaf stage on increased number of flowers. Wittweret al. (1957) showed that $\mathrm{GA}_{3}$ applied to tomato plants at the first true leaf stage produced a higher number of flowers per plant.

Comparisons among the mean values of the yield per individual plant in (Table 4) explained thatcombined treatment ( topping at the $4^{\text {th }}$ leaf stage plus $\mathrm{GA}_{3}$ at 
$40 \mathrm{mg} / \mathrm{L})$ was the most effective treatment and reflected ,statistically, the highest mean value of yield per plant(5.56ton/fed.). These results might be attributed to both increase in number and weight of fruits, induced by topping at early stage of growth plus $\mathrm{GA}_{3}$ at $40 \mathrm{mg} / \mathrm{L}$.

Regarding early yield, topping above node number 4,5 and $6^{\text {th }}$ significantly reduced early yield by $12.5,22.5$ and $47.6 \%$; as an average of the two seasons 2011 and 2012, respectively, relative to the untopping treatments (Table 4). However, when the topping plants at the previous different leaf stages were sprayed with $\mathrm{GA}_{3}$ at $40 \mathrm{mg} / \mathrm{L}$ increases in early yield were 101.1 , 45.4 and $16 \%$, compared with control ,consecutively. It is important to notice that the application of $\mathrm{GA}_{3}$ countered the effects of topping on early yield and the effect depended largelyon the concentration of $\mathrm{GA}_{3}$ and the stage of topping. These desirable effects of interactions between topping and $\mathrm{GA}_{3}$, especially at $4^{\text {th }}$ leaf stage of topping plus $\mathrm{GA}_{3}$ at $40 \mathrm{mg} / \mathrm{L}$ on early yield, could be explained on the basis that this combined treatment encourages basal branching, shorting the flowering time. Increased number of flowers and probably increased the number fruits and total weight of fruits per plant; especially at that first two pickings. Accordingly, the early yield would be increased.

According the total yield of husk tomato plants, topping treatments at 4 and $5^{\text {th }}$ leaf stages ,significantly, increased the total yield by 13.7 and $9.8 \%$, respectively,whereas topping at $6^{\text {th }}$ leaf stage significantly reduced the total yield by $8.3 \%$, as an average of the both seasons; than the untopping treatment (Table 4). At 4,5 and $6^{\text {th }}$ leaf stages of topping,with application of $\mathrm{GA}_{3}$ at $20 \mathrm{mg} / \mathrm{L}$, significantly, increased the total yield by $21.9,15.0$ and $13.0 \%$; respectively; over the control treatment. This result, also, indicated that $\mathrm{GA}_{3}$ altered the unfavorable effect of topping of the $6^{\text {th }}$ leaf stage and improved the favorable effect of topping at 4 and $5^{\text {th }}$ leaf stage on total yield. Moreover, at $40 \mathrm{mg} / \mathrm{L}$ of $\mathrm{GA}_{3}$, more favorable effects on total yield were evident since the corresponding increases in total yield at 4,5 and $6^{\text {th }}$ leaf stages of topping were 30.6, 19.4 and $15.6 \%$ as an average of the two seasons, each in turn, over the control treatment. The increases in total yields of husk tomato were mainly due to the increase in average fruit weight caused by $\mathrm{GA}_{3}$ applications and, due to the increase in number of fruits per plant; caused by the combined effect of apex removal and $\mathrm{GA}_{3}$.

\section{CONCLUSION}

The significance highest total yield value was recorded for the interaction treatment between topping of $4^{\text {th }}$ leaf-stage and $\mathrm{GA}_{3} 40 \mathrm{mg} / \mathrm{L}$, were 5.5 and 5.56 ton/fed. For 2011 and 2012, respectively, all over the other treatments. On the other hand the lowest total yield value 0.515 and 4.12 ton/fed. for 2011 and 2012, respectively. 
Table (3). Effect of apex removal (topping) and gibberllic acid combinations on flowering time, number of basal branches and number of flowers of husk tomato during both seasons(2011 and 2012)

\begin{tabular}{|c|c|c|c|c|c|c|}
\hline \multicolumn{7}{|c|}{ Seasons } \\
\hline \multicolumn{4}{|c|}{2011} & \multicolumn{3}{|c|}{2012} \\
\hline \multirow{2}{*}{ Topping at leaf- stage } & \multicolumn{3}{|c|}{$\mathrm{GA}_{3}(\mathrm{mg} / \mathrm{L})$} & \multicolumn{3}{|c|}{$\mathrm{GA}_{3}(\mathrm{mg} / \mathrm{L})$} \\
\hline & 0 & 20 & 40 & 0 & 20 & 40 \\
\hline & \multicolumn{6}{|c|}{ Flowering time (days) } \\
\hline Untopping (cont.) & $46.9 b^{*}$ & -- & -- & $43.4 \mathrm{~b}$ & -- & -- \\
\hline Fourth & $51.1 \mathrm{a}$ & $45.9 \mathrm{~b}$ & $46.6 \mathrm{~b}$ & $49.4 \mathrm{a}$ & $42.2 \mathrm{~b}$ & $45.1 \mathrm{~b}$ \\
\hline Fifth & $50.9 a$ & $45.2 \mathrm{~b}$ & $46.4 \mathrm{~b}$ & $51.4 \mathrm{a}$ & $43.3 \mathrm{~b}$ & $44.9 \mathrm{~b}$ \\
\hline \multirow[t]{2}{*}{ Sixth } & $50.5 \mathrm{a}$ & $45.3 \mathrm{~b}$ & $46.9 \mathrm{~b}$ & $52.2 \mathrm{a}$ & $42.8 \mathrm{~b}$ & $44.3 \mathrm{~b}$ \\
\hline & \multicolumn{6}{|c|}{ Basal branches no-/plant } \\
\hline Untopping (cont.) & $5.6 \mathrm{~d}$ & -- & -- & $6.1 \mathrm{e}$ & -- & -- \\
\hline Fourth & $7.1 \mathrm{c}$ & $7.1 \mathrm{c}$ & $11.8 \mathrm{a}$ & $7.7 \mathrm{~d}$ & $7.7 \mathrm{~d}$ & $13.1 \mathrm{a}$ \\
\hline Fifth & $7.9 \mathrm{c}$ & $9.6 \mathrm{~b}$ & $11.4 \mathrm{a}$ & $7.2 \mathrm{~d}$ & $11.6 \mathrm{~b}$ & $11.1 \mathrm{~b}$ \\
\hline \multirow[t]{2}{*}{ Sixth } & $7.1 \mathrm{c}$ & $11.2 \mathrm{a}$ & $11.3 \mathrm{a}$ & $7.8 \mathrm{~d}$ & $9.6 \mathrm{c}$ & $10.8 b c$ \\
\hline & \multicolumn{6}{|c|}{ Flowers number no/plant } \\
\hline Untopping (cont.) & $6.3 f$ & -- & -- & $6.5 \mathrm{~d}$ & -- & -- \\
\hline Fourth & $6.8 \mathrm{de}$ & $6.8 \mathrm{de}$ & $7.3 \mathrm{a}$ & $7.2 \mathrm{c}$ & $6.7 \mathrm{~d}$ & $8.3 \mathrm{a}$ \\
\hline Fifth & $6.9 \mathrm{cde}$ & $6.9 \mathrm{bcd}$ & $7.2 a b$ & $7.3 \mathrm{c}$ & $7.6 \mathrm{~b}$ & $7.4 \mathrm{bc}$ \\
\hline Sixth & $6.7 \mathrm{e}$ & $7.1 \mathrm{abc}$ & $7.2 \mathrm{ab}$ & $7.3 \mathrm{c}$ & $7.2 \mathrm{c}$ & $7.4 \mathrm{bc}$ \\
\hline
\end{tabular}

* Values followed by the same letter didn't significantly differ using revised L.S.D test at 0.05 level of significance 
Table (4). Effect of apex removal (topping) and gibberllic acid combinations on total yield of husk tomato and its component during both Seasons(2011 and 2012)

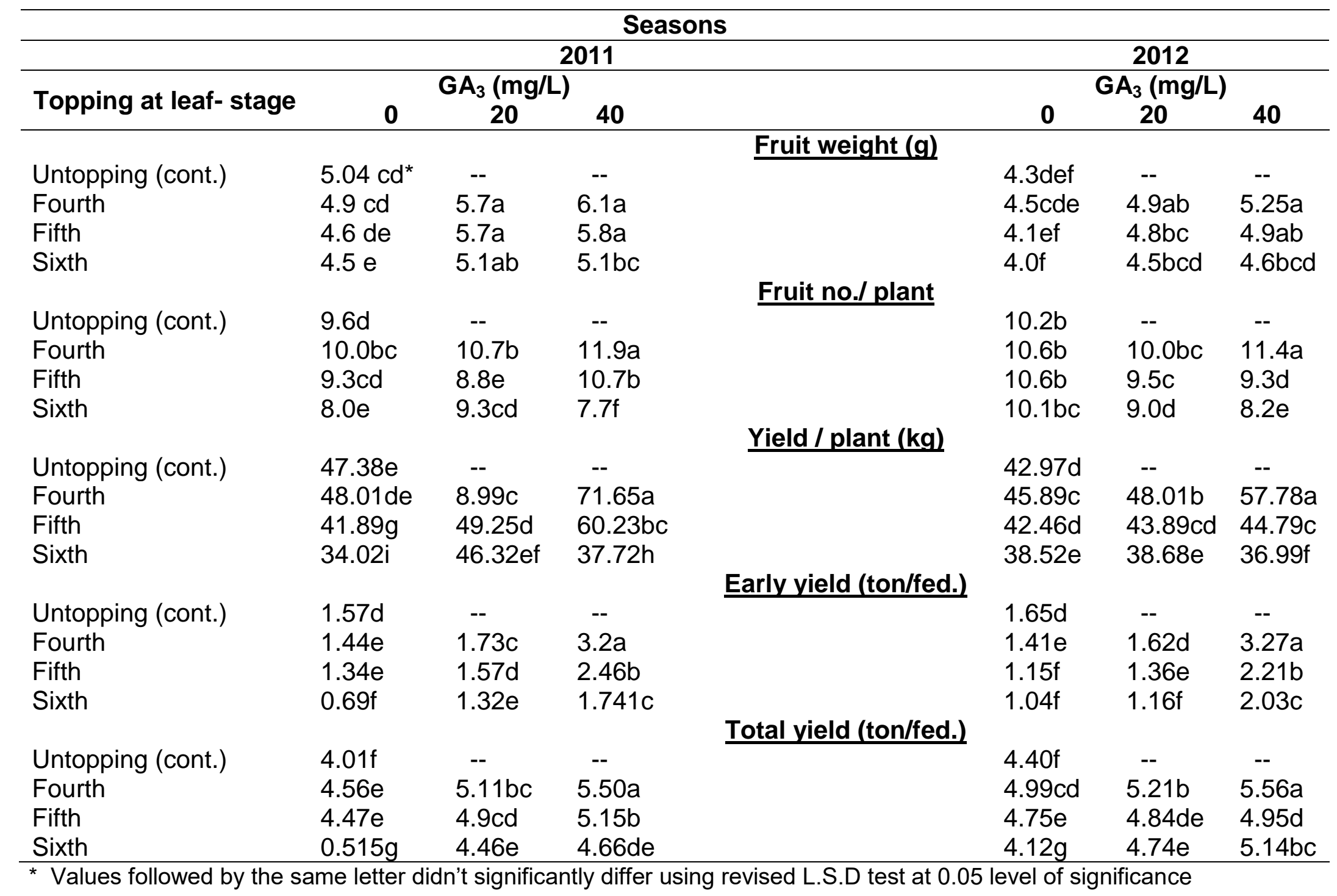




\section{REFERENCE}

Agricultural Statistics News latters (1996). Economical affairs sector, agricultural economics management center, Ministry of Agriculture and Land Reclamation. Cairo, Egypt. Vol. (4) Nov., (in Arabic).

Batal, K.M. (1983). Effects of ethepho - gibberellins combinations on yield, size quality of muskmelon. J. Amer. Soc. Hort. Sci., 108 (1): $77-80$.

Bianchini, F. and F. Corbetta (1977). Health plants. Hamlyn Colour Guides, London, $22-23$.

Charles, B.S.( 1948).Early and total yield of tomatoes as affected by time of seeding, topping the plants and space in the flats. Amer. Soc. Hort. Sci., 51: 367- 370 .

Feleafel, M.N. (2001). Effect of topping under varying levels of $\mathrm{N}$ and $\mathrm{K}$ fentilizers on growth, yield potential and quality of sweet potato. Agric. Sci. Mansoura, Univ., 26 (2): 1007 - 1019.

Ghoneim, I.M. (2000). Effect of okra plants decapitation under various nitrogen levels on growth, flowering, green pod yield and seed production. Alex. Agric. Res., 5 (5): 1405 - 1424.

Husain, S.M. and A. J. Linck (1986). Relathionship of apical dominance to the nutrient accumulation pattern in (Pisumsativum var. Alaska). Plant Physio. 19: $992-1010$.

Knott, J.E. (1928). The effect of apical pruning of tomato seedlings on growth and early yield. Proc. Amer. Soc. Hort. Sci., $24: 21-23$.

Rappaport, L.( 1957). Effect of gibberellins on growth, flowering and fruiting of early pack tomato, Lycopeersicon esculentum. Plant Physio., 32 : 440 444.

Robert, K.S. (1959). Effects of gibberellic acid on genetic characters in two tomato lines. Bot. Gaz., $121: 114-120$.

Rubinstein, B. and M.A. Nagoa (1976). Lateral bud outgrowth and its control by the apex removal. Bot. Rev., 42 (1) : $64-105$.

Sanat, K.M. (1968). Morphogenetic responses of tomato plants to combined and indicidual applications of gibberellic acid, ethephon and B- nine. Plant and soil, xxvIII (2): $291-279$.

Sawhnay, V.K. and R.I. Grayson (1971). Induction of multimolocular ovary in tomato by gibberellic acid. J. Amer. Soc. Hort. Sci., $96: 196-198$.

Sawhnay, V.K. and R.I. Grayson (1972). Fruit size increase in tomato following application of gibberellic acid. J. Amer Soc. Hort. Sci., 97 (5): 589 -590 .

Stary, F. (1983). Poisonous Plants. Hamlyn Colour Guides London.

Waller, R. A and C.B. Duncan (1969). A rule for symmetric multiple comparisons problem- Amer. Sate. Assoc. H. December: 1485 - 1503.

Westover, K. C.(1942). Futher studies on the effect of topping young tomato plants on fruit set and yield. Proc. Amer. Soc. Hort. Sci., 41: $285-288$.

Wien, H.C. and P.L. Minotte (1988). Increasing yield of tomato with plastic mulch and apex removal. J. Amer. Soc. Hort. Sci., 113 (3) : $342-347$.

Wittwer, S.H., M. H. Bukovac, H. M. Sell and L.E. Weller (1957). Same effects of gibberellins on flowering and fruit setting. Plant Physio., $32: 39-$ 41. 


\section{الملخص العربي \\ تأثير التداخل بين إزالة القمة النامية وحمض الجبريليك على الأزهار والمحصول في الحرنكش إله \\ دعاء محمد مصطفي أحمد \\ مركز البحوث الزراعية-معهد بحوث البساتين-الإسكندرية}

تهدف هذه الدراسة للوصول إلى كثف التأثنيرات المتداخلة لمعاملات إزالة القمة النامية للساق الرئيسية عند مرحلة تكوين الورقة الرابعة والخامسة والسادسة ومعاملات حمض الجبريليك بتركيزات (صفر ، 20، 40 مجم/لتز) على الإزهار والمحصول ومكوناته في الحرنكث المصري (الصنف البلدي). وقد أوضحت النتائج أن إزالة القمة النامية في مرحلة تكوين الورقة الرابعة والخامسة والسادسة أدى إلى تنشيط

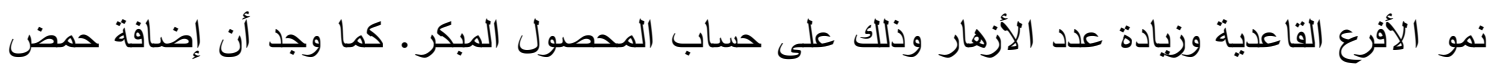
الجبريليك يتركز 20 أو 40 مجم/لتز أستطاع أن يعوض التأثير المتأخر للإزهار بسبب إزالة القمة النامية ، مع تزامن تنشيط نمو الأفرع القاعدية مقارنة بمعاملة الكنترول (وهي التي أزيلت فيها القمة النامية فقط). وقد أوضحت النتائج أن لنبات الحرنكش المقدرة على تعويض النقص في المحصول المبكر الناتج عن إزالة القمة النامية. وذللك عند إدخال المعاملة بحمض الجبريليك، ولكن هذا التعويض يتوقف على المرحلة التي تمت فيها إزالة القمة النامية وتركيز حمض الجبريليك. وقد ارتبطت الزيادة في المحصول الكلي والناثئة عن المعاملة (إزالة القمة النامية عند مرحلة الورقة الرابعة بجانب استخدام حمض الجبريليك عند تركيز 40 مجم/لتز) بزيادة حجم الثمرة وعدد الثمار للنبات الواحد. 
